\title{
A Rare case of Menetrier's disease presenting with Protein Losing Gastropathy Mimicking Carcinoma Stomach
}

Richmond Ronald Gomes

Associate Professor, Medicine, Ad-din Women's Medical College Hospital Dhaka, Bangladesh

*Corresponding Author: Richmond Ronald Gomes, Associate Professor, Medicine, Ad-din Women's Medical College Hospital Dhaka, Bangladesh

Received date: April 14, 2021; Accepted date: April 21, 2021; Published date: May 19, 2021

Citation: Richmond R. Gomes (2021 A Rare case of Menetrier's disease presenting with Protein Losing Gastropathy Mimicking Carcinoma Stomach. J. Gastroenterology Pancreatology and Hepatobilary Disorders. 5(4): DOI: 10.31579/2641-5194/025

Copyright: () 2021, Richmond R. Gomes, This is an open access article distributed under the Creative Commons Attribution License, which permits unrestricted use, distribution, and reproduction in any medium, provided the original work is properly cited.

\begin{abstract}
:
Ménétrier's disease (MD) (also known as giant hypertrophic gastritis or hypoproteinemic hypertrophic gastropathy) is a rare premalignant entity characterized by markedly hypertrophied mucosal folds of the fundus and the gastric corpus typically associated with, hypochlorhydria, protein losing enteropathy causing hypoalbuminemia and anemia. However, the natural history of MD in adults remains unclear and is rarely reported in the literature. Its constellation of classic symptoms includes nausea, vomiting, abdominal pain and peripheral edema, and it is associated with increased risk of gastric cancer. Nevertheless, its pathophysiology is not yet fully understood and clinical and endoscopic diagnosis can be difficult to establish. Malignant transformation in MD should not be overlooked, and regular monitoring of the gastric mucosa via endoscopy is necessary.
\end{abstract}

Key words: menetrier disease, hypoalbuminemia, hypochlorhydria

\section{Introduction:}

Menetrier's disease (MD) is a rare disease that was first described by the French pathologist Pierre Menetrier(1859-1935) in the Archives de Physiologie Normale et Pathologique in 1888 [1].It is a rare acquired hypertrophic gastropathy leading to dilatation of the mucus-secreting gastric pits (fovula) on the expense of the gastric glands containing the acid-producing parietal cells and pepsinogen-producing chief cells which undergoes atrophy. These changes gives the disease it characteristic features of the huge expansion of gastric mucosa, thick mucus secretion, protein loss and hypochlorhydria [2]. The prevalence is less than 1 in 200,000 individuals the disease is more dominant in middle-aged males (mean age at diagnosis is 55 years) [3] but several authors reported it in pediatric population [4]. The aetiology of MD remains unknown, although previous studies have demonstrated that MD is associated with infections, including Helicobacter pylori, CMV and herpes simplex virus $[5,7,8]$. The clinical picture includes epigastric pain and discomfort, nausea, vomiting and peripheral edema due to low serum albumin levels. MD has a recognized premalignant potential $[10,11,12]$. Also it can lead to severe uncontrollable protein loss or upper GIT bleeding [8].Medical treatment of MD includes proton pump inhibitors, high-protein diet,eradication of H. pylori [9], cetuximab (monoclonal antibody) [10] and octreotide long-acting release [4]. Also total and partial gastrectomies are attempted in managing resistant cases.

\section{Case Report:}

In October 2020, a 70-years-old man, not known to have diabetes or hypertension was admitted to Ad-din Women's Medical College Hospital
(Dhaka ,Bangladesh) with recurrent non radiating upper abdominal pain, bloating, heartburn, bilateral leg swelling and weight loss of $7 \mathrm{~kg}$ experienced for a duration of 1 year. The pain aggravated with taking meal and of moderate severity. There was intermittent vomiting. There was no history of abdominal mass, hematemesis or melana. He also denied any shortness of breath, dark urine or reduced urinary output. The patient's medical history included hyperlipemia and benign prostatic hyperplasia. The patient had been a smoker for 20 years prior to quitting smoking in 2014, and denied drinking alcohol. The family history was considered to be noncontributory.

Upon physical examination, the patient was cachectic, pale with no jaundice. Pedal edema was present. Jugular venous pressure not raised. There were also no skin or nail changes. On investigation, $\mathrm{CBC}$ revealed hemoglobin, $4.8 \mathrm{~g} / \mathrm{dl}$; normal range, $12.0-16.0 \mathrm{~g} / \mathrm{dl}$, MCV $68.2 \mathrm{fL}$, normal 78-98 fL, MCH- 22.4 pg, normal 27-32 pg, Peripheral blood filmmicrocytic hypochromic anemia with plenty of pencil and target cells. Serum ferittin $8.80 \mathrm{ng} / \mathrm{ml}$ (normal 20-250 ng/ml). There was hypoalbuminemia (albumin, $18.99 \mathrm{~g} / \mathrm{l}$; normal range, 35-52 g/l). Serum tumor markers including carcinoembryonic antigen, $\alpha$-fetoprotein, carbohydrate antigen (CA) 125 and CA199 were within normal ranges. A chest X-ray and abdominal ultrasound were normal, as were the results of an electrocardiogram. Upper gastrointestinal endoscopy was subsequently performed with an Olympus GIF-Q180 gastroscope (Olympus Corporation, Tokyo, Japan), which revealed big circumferential ulcerated growth seen at antrum (Figure 1\&2). CLO test was negative. 

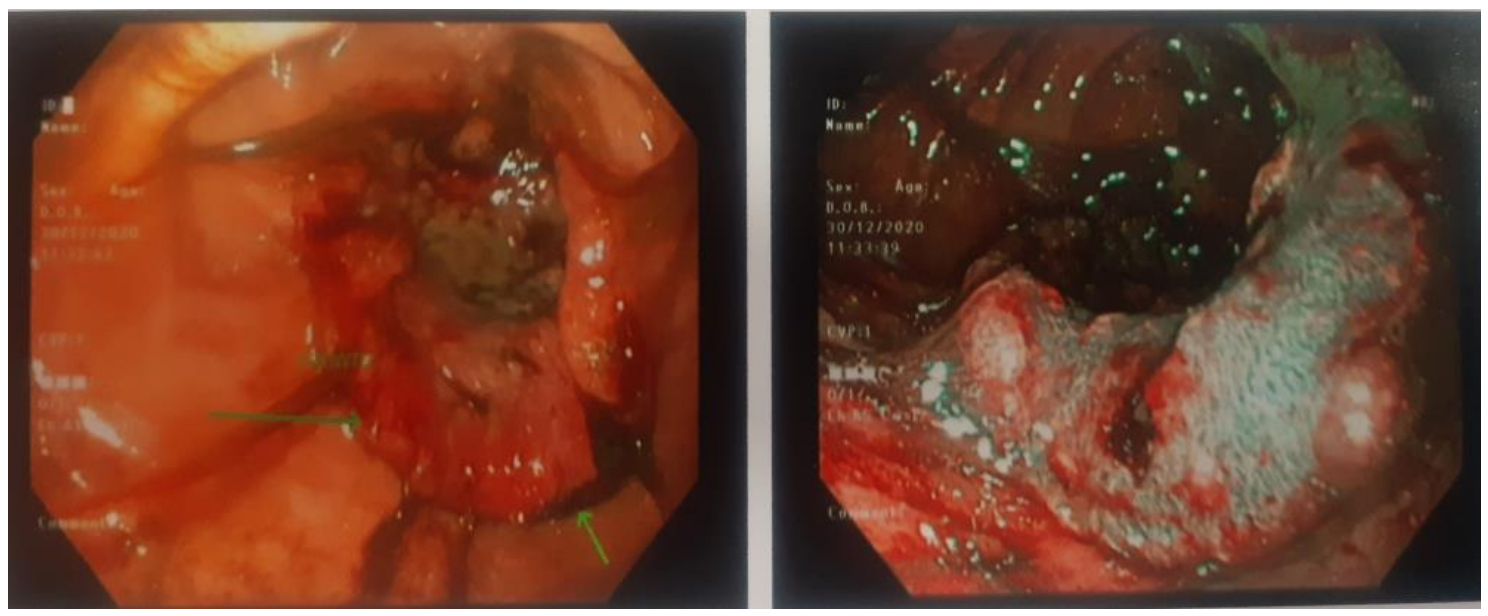

Figure 1 \& 2: Upper gastrointestinal endoscopy revealing big circumferential ulcerated growth at antrum.

Histopathology of the gastric mass revealed hyperplasia of foveolar mucus cell, the glands are elongated with cork screw like appearance and cystic dilatation.

Therefore, a diagnosis of MD was concluded. The patient was transfused 3 units of packed red cells. In order to control the patient's symptoms of recurrent upper abdominal pain, bloating, acid regurgitation, heartburn, esomeprazole ( $20 \mathrm{mg}$ twice daily) was administered. The patient was discharged as an outpatient.Three weeks later, the patient's hypoalbuminemia was resolved after an albumin level of $37 \mathrm{~g} / \mathrm{l}$ was reached, and hemoglobin levels increased to $12.8 \mathrm{~g} / \mathrm{dl}$. There is a plan to follow him up by surveillance endoscopy once or twice per year.

\section{Discussion:}

The diagnosis of MD remains an everlasting challenge. This is due to the rare nature of the disease and the lack of clear diagnostic criteria.

We could not find an exact estimate of MD incidence in literature except that is "rare". This explains why the diagnosis of the huge gastric folds can be mixed with other types of unhealthy growths like gastric polyps or polyposis syndromes [2], Hypertrophic hypersecretory gastropathy with protein loss [14], Zollinger-Ellison syndrome and gastric malignancies [12]. Rich et al. [2], proposed an algorithm for the diagnosis of MD that rely on clinicohistopathological analysis of the following criteria: upper GIT endoscopy with gastric $\mathrm{pH}$, appropriate laboratory tests $(\mathrm{CBC}$, serum albumin, serum gastrin, H. pylori and CMV) and full thickness mucosal biopsy. This is to be correlated with classic clinical features of epigastric pain, nausea and vomiting due tothe local effect of the huge gastric folds, in addition to peripheral oedema due to the protein losing nature of the disease that leads to hypoalbuminemia.

Menetrier's disease is most often found in men between the ages of 30 and 60 years although cases have also been reported in childhood. The natural history of the disease may vary considerably between adults and children. In childhood, the disorder is typically arises suddenly and resolves spontaneously, and has been associated with cytomegalovirus (CMV) infection [5]. By contrast, in adults, the course of the disease is progressive with an insidious onset [6].Clinically, patients present abdominal pain, nausea, vomiting and edema of the peripheral tissues (imbalance of osmotic pressure due to the selective filtration of proteins through the gastric mucosa)[13]. This disease tends to be progressive, although its pathophysiology is still unknown. Transgenic mice models overexpress transforming growth factor alpha (TGF- $\alpha$ ) in the stomach and undergo changes that resemble those found in Menetrier's disease. In addition, the receptor for epidermal growth factor (EGF) in foveolar mucus cells is overstimulated by TGF- $\alpha$, its ligand, which causes excess mucus secretion and malabsorption of nutrients.

From the clinical point of view, onset is usually insidious and progressively includes characteristics that are associated with increased risks of gastric cancer. Although the magnitude of this risk is not entirely clear, various authors place it between $0 \%$ and $10 \%[13,15]$.Variants with abrupt onsets have also been described. These have been reported most frequently in relation to spontaneous remission related to treatment of associated cytomegalovirus (CMV) infection or $\mathrm{H}$. pylori infections. Some authors have also described associations with autoimmune diseases such as inflammatory bowel disease, sclerosing cholangitis and ankylosing spondylitis which suggests that there is an immunological component which has not yet been fully elucidated $[2,16]$. Another distinctive feature of our case is that it was not associated with $\mathrm{H}$. pylori infection.

Endoscopically, the folds of the gastric mucosa are markedly thick especially in the fundus and the corpus rather than in the antrum. Gastric $\mathrm{pH}$ is high due to the loss of parietal cells, and there is copious production of thick mucus secondary to foveolar hyperplasia that occurs most commonly in the mucosa. This causes mucosal thickness to increase by one $\mathrm{cm}$ or more (in our clinical case it reached $5 \mathrm{~cm}$ ). This is a necessary condition for diagnosis [16].

Histological alterations include reduced numbers of parietal cells and main cells and atrophied oxyntic glands. Deep glands may be cystically dilated and predominantly chronic inflammatory cells with dispersed eosinophils infiltrate the lamina propria in variable amounts. Smooth muscle hyperplasia and edema are associated with decreased numbers of fundic glands which are replaced by mucous glands (pseudopyloric metaplasia). This totally abnormal mucosal architecture generates loss of protein which is frequently increased by superficial ulcers $[15,16,17]$.

Differential diagnosis revolves around other entities that thicken gastric folds. These include lymphocytic gastritis, polyposis syndromes, hyperplastic polyps, plastic lymphadenitis and lymphoma. EUS is a useful tool for differential diagnosis since it can exclude a thickening of vascular origin in cases where biopsies may cause significant bleeding. Consequently, it is recommended that EUS precede any decision to take biopsies in cases of thickening of gastric folds. Thickening originating in the second echoic layer supports a diagnosis of Menetrier's disease [17, $18]$.

Treatment is usually surgical, and partial or total gastrectomy is currently considered the treatment of choice. Nevertheless, several drug therapies have been proposed. They include weekly administration of cetuximab 
which has improved patients' quality of life. Despite this, some patients followed up for 40 months required long-term gastrectomy, so the use of cetuximab has only been recommended as the first line for management of Menetrier's disease in cases of relapses after gastrectomies [17]. Other drugs including famotidine and cimetidine have shown favorable results including reports of decreased symptoms. In the case of cimetidine, decreased protein loss has also been reported. Steroids and antibiotics have also been used but with conflicting results. It should be noted that, given the low prevalence of this disease, none of these treatments have had clinical trials with the required methodological rigor, so all reports are now considered anecdotal experiences [19].

\section{Conclusion:}

MD should be suspected in cases of upper GIT symptoms and hypertrophied gastric mucosa with or without $H$. pylori or hypoalbuminemia. MD is a rare type of hypertrophic gastropathy and currently does not have a gold-standard therapy. Treatment with octreotide had little effect on the gastric mucosa, while antimicrobial combination therapy provided no benefit in H. pylori-negative MD. Furthermore, although there was no evidence of carcinoma in the present patient, malignant transformations in MD should not be overlooked, and it is necessary to monitor the gastric mucosa via routine endoscopy.

\section{References:}

1. R.J.Coffey, J. Tanksley, (2012) Menetrier and his disease, Trans. Am. Clin. Climatol.Assoc. 123 126-134

2. A.Rich, T.Z. Toro, J. Tanksley, W.H. Fiske, C.D. Lind, G.D. Ayers, et al.,Distinguishing Menetrier's disease from its mimics, Gut 59 (2010)1617-1624.

3. A.R. Sweeney, M.K. Lynch, (2013) A case of Menetrier's disease localized to the gastric antrum without helicobacter infection or hypoalbuminemia, Int. J.Surg. Case Rep. 4 839841.

4. G. Di Nardo, S. Oliva, M. Aloi, F. Ferrari, S. Frediani, A. Marcheggiano, et al., Apediatric non-protein losing Menetrier's disease successfully treated withoctreotide long acting release, World J. Gastroenterol. 18 (2012) 2727-2729

5. Eisenstat DD, Griffiths AM, Cutz E, Petric M and Drumm B: Acute cytomegalovirus infection in a child with Ménétrier's disease. Gastroenterology. 109:592-595. 1995. View Article : Google Scholar : PubMed/NCBI

6. Scharschmidt BF(1977): The natural history of hypertrophic gastrophy (Menetrier's disease). Report of a case with 16 year follow-up and review of 120 cases from the literature. Am J Med. 63:644-652 . View Article : Google Scholar : PubMed/NCBI

7. Badov D, Lambert JR, Finlay M and Balazs ND (1998): Helicobacter pylori as a pathogenic factor in Mene trier's disease. Am J Gastroenterol. 93:1976-1979. View Article : Google Scholar : PubMed/ NCBI

8. Jun DW, Kim DH, Kim SH, Song MH, Lee HH, Kim SH, Jo YJ and Park YS (2007): Menetrier's disease associated with herpes infection: Response to treatment with acyclovir. Gastrointest Endosc. 65:1092-1095. 2007. View Article : Google Scholar : PubMed/NCBI

9. A. Fretzayas, M. Moustaki, E. Alexopoulou, P. Nicolaidou, Menetrier's disease associated with Helicobacter pylori: three cases with sonographic findings anda literature review, Ann. Trop. Paediatr. 31 (2011) 141-147

10. W.H. Fiske, J. Tanksley, K.T. Nam, J.R. Goldenring, R.J.C. Slebos, D.C. Liebler,et al. (2009), Efficacy of cetuximab in the treatment of Menetrier's disease, Sci.Transl. Med. 18 ra18.

11. M. Jouini, R. Ksontini, M.J. Kacem, S. Haouet, A. Ammous, F. Gargouri, et al. (1996),Menetrier disease associated with a gastric adenocarcinoma: apropos of 2cases, Ann. Gastroenterol. Hepatol. (Paris) 31 341-345

12. J. Kim, J.H. Cheong, J. Chen, W.J. Hyung, S.H. Choi, S.H. Noh (2004), Menetrier'sdisease in Korea: report of two cases and review of cases in a gastric cancerprevalent region, Yonsei Med. J. 45 555-560.

13. Coffey RJ Jr, Tanksley J.( 2012) Pierre Ménétrier and his disease. Trans Am Clin Climatol Assoc.;123:126-33.

14. J. Byun, S. Kwon, S.Y. Oh, K.G. Lee, Y.S. Suh, S.H. Kong, et al., Laparoscopic management of hypertrophic hypersecretory gastropathy with protein loss: acase report, Asian J. Endosc. Surg. 7 (2014) 48-51.

15. Huh WJ, Coffey RJ, Washington MK. Ménétrier's Disease: Its Mimickers and Pathogenesis. J Pathol Transl Med. 2016;50(1):10-6.

16. Patel M, Mottershead M. (2014) Disease recurrence following cetuximab completion and declining a gastrectomy: what next to manage Ménétriers disease? BMJ Case Rep.;2014. pii: bcr2014204954.

17. Fiske WH, Tanksley J, Nam KT, Goldenring JR, Slebos RJ, Liebler DC, et al (2009). Efficacy of cetuximab in the treatment of Menetrier's disease. Sci Transl Med.;1(8):8ra18.

18. Azer M, Sultan A, Zalata K, Abd El-Haleem I, Hassan A, ElEbeidy G (2015). A case of Menetrier's disease without Helicobacter pylori or hypoalbuminemia. Int J Surg Case Rep.;17:58-60.

19. Silva PH, Rigo P, Batista RP, Toma RK, Oliveira LA, Suzuki L. (2016) Ménétrier's disease associated with gastric adenocarcinoma in a child - imaging aspect. Rev Assoc Med Bras 62(6):485-9.

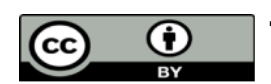

This work is licensed under Creative Commons Attribution 4.0 License
To Submit Your Article Click Here: Submit Manuscript

DOI: $10.31579 / 2641-5194 / 025$

$$
\begin{aligned}
& \text { Ready to submit your research? Choose Auctores and benefit from: } \\
& \text { *ast, convenient online submission } \\
& \text { rigorous peer review by experienced research in your field } \\
& \text { rapid publication on acceptance } \\
& \text { - unthors retain copyrights } \\
& \text { immediate, unrestricted online access }
\end{aligned}
$$

At Auctores, research is always in progress.

Learn more www.auctoresonline.org/journals/gastroenterologypancreatology-and-hepatobilary-disorders 